\title{
Environmental DNA characterization of amphibian communities in the Brazilian Atlantic forest: Potential application for conservation of a rich and threatened fauna
}

\author{
Thais Sasso $^{\mathrm{a}, *}$, Carla M. Lopes ${ }^{\mathrm{b}}$, Alice Valentini ${ }^{\mathrm{c}}$, Tony Dejean ${ }^{\mathrm{c}}$, Kelly R. Zamudio ${ }^{\mathrm{d}}$, \\ Célio F.B. Haddad ${ }^{\mathrm{b}}$, Marcio Martins ${ }^{\mathrm{a}}$ \\ a Departamento de Ecologia, Instituto de Biociências, Universidade de São Paulo, 05508-090 São Paulo, SP, Brazil \\ b Universidade Estadual Paulista (UNESP), Departamento de Zoologia, Instituto de Biociências e Centro de Aquicultura (CAUNESP), Campus Rio Claro, 13506-900 Rio \\ Claro, SP, Brazil \\ c SPYGEN, Savoie Technolac, BP 274, Le Bourget-du-Lac 73375, France \\ d Department of Ecology and Evolutionary Biology, Cornell University, Ithaca, NY 14853, USA
}

\section{A R T I C L E I N F O}

\section{Keywords:}

eDNA metabarcoding

Biodiversity assessment

$12 S$ rRNA mitochondrial gene

Community sampling

High throughput sequencing

\begin{abstract}
A B S T R A C T
The Brazilian Atlantic forest is a highly threatened biodiversity hotspot, harboring one of the highest levels of amphibian species richness in the world. Amphibian conservation in Neotropical biomes is critical because freshwater ecosystems typically experience sharp declines in biodiversity before much is known about species that depend on those environments. Environmental DNA (eDNA) analysis is a new approach for monitoring aquatic organisms and provides valuable information on species occurrence in freshwater ecosystems. Here, we assess community diversity in Neotropical streams using eDNA metabarcoding. We compare data from a fiveyear traditional field survey with results from a short-term eDNA analysis in four streams of the Atlantic forest of southeastern Brazil. We recorded 19 species over 5 years using visual-acoustic methods, of which 10 species are associated with the streams during at least one life stage (egg, tadpole or post-metamorphic). We were able to detect nine of the latter species using eDNA metabarcoding from water samples collected over 4 days. Amphibian community composition as measured by both methods showed high similarity in three streams, but was not perfect, as eDNA failed to detect known species in a fourth stream. Furthermore, in one stream we detected through eDNA metabarcoding a species (Aplastodiscus eugenioi) found only once during the 5-year traditional survey in that stream. Also, three species (Cycloramphus boraceiensis, Hylodes asper, and Hylodes phyllodes) with the highest dependence on aquatic habitat showed the highest number of positive PCR detections on eDNA samples. Our results showed that eDNA metabarcoding can be a useful tool to assess community diversity in tropical streams, and although not perfect in detection, this method can potentially improve our ability to conserve Neotropical amphibians.
\end{abstract}

\section{Introduction}

The Brazilian Atlantic forest is home to a high diversity of amphibians, harboring over 500 species (approximately 7\% of all known species) of which $88 \%$ are endemic to this biome (Haddad et al., 2013). Distributed along the coast of eastern Brazil, the Atlantic forest covers mountainous terrains with a large number of high-gradient streams (Morellato and Haddad, 2000). These freshwater environments harbor a high diversity of amphibians, including habitat specialists with most or all life cycle stages depending on lotic waters (Haddad et al., 2013). The Atlantic forest is also one of the most threatened tropical ecosystems in the world (Myers et al., 2000) with only 16\% of its original vegetation cover remaining (Ribeiro et al., 2009), posing a high risk to habitat specialists endemic to this biome. Several other factors, such as invasive species, and emergent infectious diseases (Both et al., 2011; Carvalho et al., 2017; Eterovick et al., 2005) also potentially contribute to observed amphibian declines in Atlantic forest. Not surprisingly, approximately $88 \%$ of the threatened anuran species in Brazil are from the Atlantic forest (ICMBio, 2016a) and most of the documented frog declines in Brazil include species closely associated with streams (Eterovick et al., 2005). Furthermore, over one fifth of Atlantic forest amphibians that are stream specialists lack baseline data and are

\footnotetext{
* Corresponding author at: Departamento de Ecologia, Instituto de Biociências, Universidade de São Paulo, Rua do Matão, Trav. 14 no. 321 , 05508-090 São Paulo, SP, Brazil.

E-mail address: thais.lopes@usp.br (T. Sasso).
} 
listed as Data-Deficient according to the International Union for Conservation of Nature (IUCN, 2015; ICMBio, 2016b). Thus, it is critical to describe the occurrence and distribution of stream frog species in the Atlantic forest and any method that makes this task easier and more precise will be of crucial importance for amphibian conservation.

Field techniques traditionally used to assess amphibian occurrence require a large investment in fieldwork and come with their own sources of error (Heyer et al., 1993). For instance, frog detectability through acoustic survey are highly variable among species, some species call only a few days per year making their detection less likely, and all types of traps used to sample amphibians (e.g., pitfall, funnel, pipe) provide biased results (Dodd, 2010; Petitot et al., 2014). Recently, the analysis of environmental DNA (eDNA) has emerged as a promising alternative approach for detecting aquatic species. The term eDNA refers to DNA shed by an organism in the environment, such as water, soil, or even air (Taberlet et al., 2012a), which can be then sampled for sequencing and species identification (Bohmann et al., 2014). The use of eDNA has recently gained widespread attention because it allows researchers to detect species even at low abundances (Dejean et al., 2012) and during short term field samplings (Lopes et al., 2017), making eDNA ideal for applications in conservation biology.

The number of ecological studies applying eDNA analysis to monitor species is increasing, yet few studies have sampled eDNA from aquatic environments to perform broad community surveys (but see Shaw et al., 2016; Valentini et al., 2016). Most eDNA efforts have focused on detection of a particular species using species-specific molecular markers (Thomsen and Willerslev, 2015). These efforts, while valuable, do not assess species diversity. If the goal is to survey the biodiversity of particular taxa and assess community composition, one can use DNAbased identification of a group of species at a locality with universal primers, an approach known as "DNA metabarcoding" (Taberlet et al., 2012b).

Here we report the results of a short-term eDNA metabarcoding study applied to a system of Atlantic forest streams where amphibian community composition was well known through a long-term traditional survey. By comparing our eDNA results with our traditional survey, we assess the utility of the eDNA metabarcoding for the characterization of tropical frog communities from a megadiverse region. If one or a few eDNA samples can accurately describe amphibian community composition in tropical streams, instead of long-term, time and labor-expensive traditional surveys, this method has high potential for use in conservation studies of Atlantic forest frogs.

\section{Material and methods}

\subsection{Study site}

Our study site is located within the Parque Estadual da Serra do Mar, Núcleo Picinguaba, municipality of Ubatuba, São Paulo, southeastern Brazil (see Fig. 1 in Lopes et al., 2017). The climate is tropical (Köppen, 1948) with mean annual air temperature of $26.7^{\circ} \mathrm{C}$, high and constant air humidity (monthly means 85-90\%), and an annual average rainfall of $2650 \mathrm{~mm}$ (CIIAGRO, 2016). We collected data from four freshwater mountain streams in separate drainages. During water sampling for eDNA analyses, water temperature ranged from 20.4 to $20.9^{\circ} \mathrm{C}$ and $\mathrm{pH}$ from 6.5 to 7.0 . The structure of each stream varied as follows: Stream $1\left(23^{\circ} 21^{\prime} 15.2^{\prime \prime} \mathrm{S}, 44^{\circ} 46^{\prime} 3.2^{\prime \prime} \mathrm{W}\right)$ is the largest stream sampled (4-15 $\mathrm{m}$ wide) and runs along a flat area with many large pools and few waterfalls; Stream $2\left(23^{\circ} 21^{\prime} 34.4^{\prime \prime} \mathrm{S}, 44^{\circ} 47^{\prime} 3.2^{\prime \prime} \mathrm{W}\right)$ is the smallest stream sampled (1-5 m wide), it ceases to flow during the driest periods of the driest years, runs along a flat area in the first $40 \mathrm{~m}$, sloping for much its length, before reaching a steep area; Stream $3\left(23^{\circ}\right.$ $21^{\prime} 41.2^{\prime \prime} \mathrm{S}, 44^{\circ} 47^{\prime} 15.3^{\prime \prime} \mathrm{W}$ ) has a lower inclination than the other streams sampled, with fewer waterfalls and many large pools, and its width varies from 5 to $10 \mathrm{~m}$; and Stream 4 ( $23^{\circ} 21^{\prime} 53.7^{\prime \prime} \mathrm{S}, 44^{\circ} 48^{\prime} 2.8^{\prime \prime}$ $\mathrm{W}$ ) is the most sloping of the four streams, with many waterfalls and few large pools, and its width varies from 5 to $10 \mathrm{~m}$. We purposefully chose these four streams because they are first (Stream 2) and second (the remaining three) -order wadeable streams, but vary in habitat characteristics that potentially change amphibian community composition and abundance, and thus are excellent sites for testing the efficacy of the eDNA application to community level questions.

\subsection{Traditional survey}

We surveyed the four focal streams for species composition monthly from January 2007 to December 2010, and every other month in 2011, for a total of 55 monthly surveys over the course of five years. Surveys were primarily visual and complemented with call identifications. We surveyed twice per month (one diurnal and one nocturnal survey) within a 95-115 m transect along each stream with three observers. We searched for post-metamorphic individuals (froglets to adults) while walking slowly upstream for 30 to $60 \mathrm{~min}$. Phasmahyla cruzi Carvalho-eSilva et al., 2009 was also recorded with visual survey for tadpoles, which are easy to identify and conspicuous in stream ponds. We did not use tadpole records for other species because of their cryptic nature and difficulty in species identification.

The time gap between our traditional and eDNA surveys could be a potential problem in our study design if populations and communities of our streams vary significantly over time. However, we sampled these streams for 20 days in July 2001, every month from February 2006 to January 2011, every two months from March 2011 to December 2011, as well as during the four days we sampled for eDNA in April 2015. The average encounter rate of individuals of at least six species commonly found in these streams [Cycloramphus boraceiensis Heyer, 1983, Hylodes asper (Müller, 1924a), H. phyllodes Heyer and Cocroft, 1986, Phasmahyla cruzi, Vitreorana uranoscopa (Müller, 1924b), Ololygon trapicheiroi (Lutz and Lutz, 1954), and Thoropa taophora (Miranda-Ribeiro, 1923)] remained constant during this entire period (Ruggeri et al., 2015; M.M. unpublished data). Based on these observations we infer that the frog communities of these streams did not change considerably from the time of our traditional surveys to that of our eDNA survey.

\subsection{Detection protocol for eDNA}

Collections of eDNA samples were performed in a single four day period (22-25 April 2015; one stream each day). Air and water temperatures remained relatively constant during the sampling period. No sampling was performed during the hours following occasional rain showers. We followed the protocols described in Lopes et al. (2017) for eDNA sampling, DNA extraction, PCR amplification, DNA purification, next-generation sequencing, and bioinformatics analyses. Briefly, we filtered water at two locations per stream within the same 95-115 m transects in which traditional surveys were performed. Sampling point 1 was located at the beginning of the transect $(\sim 0 \mathrm{~m})$ and sampling point 2 was located at the end of the transect $(\sim 100 \mathrm{~m})$. To avoid water contamination and perturbation, sampling was first performed at sampling point 1 and proceeded upstream to sampling point 2 . At each location we filtered $60 \mathrm{~L}$ of water directly from the water column through a disposable capsule (Envirochek HV $1 \mu \mathrm{m}$, Pall Corporation, Ann Arbor, MI, USA) using a peristaltic pump (1.60 $\mathrm{L} \mathrm{min}^{-1}$, model 410 , Solinst, Canada). We also filtered $5 \mathrm{~L}$ of distilled water to serve as negative control and assess possible sources of contamination from handling procedures in the field. Capsules were filled with $150 \mathrm{~mL}$ of buffer solution (Tris- $\mathrm{HCl} 0.1 \mathrm{M}$, EDTA $0.1 \mathrm{M}, \mathrm{NaCl} 0.01 \mathrm{M}$, and $N$ lauroyl sarcosine $1 \%$, $\mathrm{pH} 7.5-8$ ) to prevent DNA degradation and stored at room temperature until processing in the laboratory.

DNA extraction and PCR procedures were done at SPYGEN (Le Bourget du Lac, France) following previously published extraction and amplification protocols (Lopes et al., 2017). A negative DNA extraction control was added to monitor possible laboratory contamination. Briefly, a short fragment ( $\sim 52 \mathrm{bp}$ ) of the $12 \mathrm{~S}$ rRNA mitochondrial gene 
was amplified using the batra_F (5'-ACACCGCCCGTCACCCT- $3^{\prime}$ ) and batra_R (5'-GTAYACTTACCATGTTACGACTT-3') primers (Valentini et al., 2016). Blocking primers for human DNA (batra_blk, 5'-TCACCCTCCTCAAGTATACTTCAAAGGCA-SPC3I-3') (Valentini et al., 2016) were used to avoid undesired amplification and increase the specificity of the amplicons (Wilcox et al., 2014). We replicated each DNA extract in 12 independent PCR reactions. One negative PCR control containing ultrapure water was analyzed in parallel with the samples. Pair-end sequencing $(2 \times 125 \mathrm{bp})$ was carried out using an Illumina HiSeq 2500 sequencer (Illumina, San Diego, CA, USA) with HiSeq SBS Kit v4 (Illumina, San Diego, CA, USA), following the manufacturer's instructions at Fasteris facilities (Geneva, Switzerland).

\subsubsection{Species reference database}

To identify species whose eDNA was collected in water samples, we used the 12S rRNA mitochondrial reference database of anuran species described in Lopes et al. (2017), using the programs ecoPCR (Ficetola et al., 2010) and OBITools (Boyer et al., 2016). The reference database was composed of (i) a local database with $12 \mathrm{~S}$ sequences for 36 anuran species, from the 44 known to occur at Núcleo Picinguaba, based on Hartmann's (2004) amphibian community list for this region and (ii) anuran species sequences from the release vrt124 of the European Molecular Biology Laboratory (EMBL) database, also corresponding to the metabarcode region. From both the EMBL sequences and the ones we generated ourselves, we identified and extracted the metabarcode sequence between the batra $\mathrm{F}$ and batra $\mathrm{R}$ primers, and imported those fragments in to the reference database. We accepted metabarcode sequences that were $20-100$ base pairs in length and allowed 2 bp errors per primer. We retained 3425 sequences from 47 anuran families from the EMBL database (see Lopes et al., 2017 for more details on methodology).

\section{4. eDNA data analyses}

Sequences resulting from the water samples were filtered and annotated using custom pipelines in OBITools (Boyer et al., 2016) and R (v 3.1.3; R Development Core Team, 2015). We detected and eliminated sequences not properly identified by the primers (only $2 \mathrm{bp}$ mismatches per primer allowed) and molecular tags (no mismatch allowed). Only sequences having a length longer than $20 \mathrm{bp}$ and more than ten read counts were kept. We then assigned sequences to a corresponding taxon based on sequence similarity with the species reference database. To avoid errors from PCR and sequencing procedures, we discarded sequence records with frequency below 0.001 . We excluded sequences potentially coming from cross-contamination sources with frequency below 0.003 per sample. We kept only sequences with high identity percentage (i.e. that match with $>96 \%$ to the sequences from the reference database). We considered a species present if at least one of the 12 PCR replicates showed positive detection (see Lopes et al., 2017 for more details on methodology).

Sequence conflict occurred for six species in the complete reference database due to mislabeled sequences in the EMBL database. Identical sequences for Thoropa miliaris (Spix, 1824) and T. taophora were accessioned before the recent taxonomic revision of the group (Feio et al., 2006). In this case, we assumed the query sequence to be T. taophora because $T$. miliaris does not occur in the study area. Similarly, taxonomic ambiguity affected species assignment to Phasmahyla guttata (Lutz, 1924), P. cruzi, Bokermannohyla hylax (Heyer, 1985) and Bokermannohyla sp. (aff. circumdata), taxa which lack recent taxonomic revision. In both cases, ambiguous sequences were assigned to the latter taxon, which are known to inhabit the study area.

\subsection{Community-level data analyses}

We quantified the constancy of each species in each stream in monthly traditional samplings, using the formula $\mathrm{C}=\mathrm{P} \times 100 / \mathrm{N}$
(Silveira-Netto et al., 1976), where: $\mathrm{P}=$ number of months a certain species was detected; $\mathrm{N}=$ total number of months (all months pooled across the 5 -year traditional surveys; here $N=12$ ). We pooled the yearly data by month because the species detected in our stream varied largely in frequency, either due to detectability or species-specific densities. Some species were closely associated with the streams and easily sampled [e.g. Cycloramphus boraceiensis, Hylodes asper, H. phyllodes, Ololygon trapicheiroi, Phasmahyla cruzi, and Vitreorana uranoscopa], and other species were detected only occasionally [visually or by their calls; Bokermannohyla sp. (aff. circumdata), Dendropsophus minutus (Peters, 1872), Hypsiboas albomarginatus (Spix, 1824)]. The constancy index (C) ranges from 0 to $100 \%$. Based on the constancy index, the species were classified as: (i) constant species, if present in 7 months or more (C $>50 \%$ ), (ii) occasional species, if present in 4 to 6 months (C $=33-50 \%)$, (iii) accidental species, if present in 1 to 3 months ( $C=8.3-25 \%$ ), and (iv) absent species, if the species was never recorded ( $C=0 \%$; cf. Silveira-Netto et al., 1976). We also compiled species composition only for the month of April pooled across the 5 years of traditional survey, the same month that environmental DNA samplings were performed. Additionally, to allow for variation in climatic conditions in different years, and consequently, seasonal changes in community composition, we also compared eDNA results with data summed from the months of March, April, and May pooled across 5 years. We used linear regressions to assess the relationship between the constancy index for each species at each stream and the mean proportion of positive PCR replicates for each species obtained at two sampling points at each stream.

We used field observations and searched the literature to characterize the habitat of all life cycle stages for each species found in the study area. We classified egg, larval, and adult habitats as non-aquatic or ponds far $(>20 \mathrm{~m})$ from streams (attributed a value $=0$ ), ponds adjacent $(<20 \mathrm{~m})$ to streams (attributed a value $=1$ ), or along or within the watercourse of the stream (attributed a value $=2$; modified from Lips et al., 2003). We summed the value attributed to each life stage habitat to calculate a riparian habitat index (HI) for each species (modified from Lips et al., 2003). The HI varies from 0 to 6 and estimates the degree of contact of a species with a riparian environment, and was used as a proxy for the expected shedding of DNA into the stream water we sampled. We tested for correlation between the HI (including only species with $\mathrm{HI}>0$, i.e., those with at least one life stage occurring adjacent or within streams) and the mean of the proportion of positive PCR replicates at the two sampling points from each stream using Spearman's rank correlation.

We quantified species composition similarity at each stream using Jaccard's index $(S)$ between eDNA metabarcoding and traditional survey results obtained during: (i) all months sampled, (ii) the months of March, April, and May, and (iii) only the month of April. As we expect to detect primarily riparian species sampling aquatic eDNA, we calculated $S$ taking into account only species with $\mathrm{HI}>0$. Jaccard's index is based on presence/absence data and higher values of $S$ indicate higher similarity in species composition (Krebs, 1998). All analyses were performed in R (v 3.1.3; R Development Core Team, 2015).

\section{Results}

During five years of traditional surveys at the four focal streams we found a total of 19 amphibian species representing 11 families and 17 genera (Table 1). Ten of the 19 species found have at least one life stage occurring adjacent to or within streams (HI $>0$; hereafter stream species; Table 1). The remaining nine species have no association with streams ( $\mathrm{HI}=0$; hereafter non-stream species; Table 1$)$. Among stream species, the riparian habitat index ranged from 1 to 6 (Table 1).

We detected anuran DNA at all eight eDNA sampling points. All field, DNA extraction, and PCR negative controls turned out negative after the bioinformatics filtering protocol. We detected DNA of nine of the ten stream species recorded by traditional surveys (Table 2). In 
Table 1

Coded habitat of eggs, tadpoles, and adults, and riparian habitat index (HI) for all species found through traditional surveys (from 2007 to 2011). $0=$ Non-aquatic habitat or ponds far $(>20 \mathrm{~m})$ from streams, $1=$ ponds adjacent $(<20 \mathrm{~m})$ to streams, and $2=$ along or within the watercourse of the stream.

\begin{tabular}{|c|c|c|c|c|}
\hline Species & Egg & Tadpole & Adult & HI \\
\hline \multicolumn{5}{|l|}{ Brachycephalidae } \\
\hline Ischnocnema sp. (aff. guentheri) & 0 & 0 & 0 & 0 \\
\hline \multicolumn{5}{|l|}{ Bufonidae } \\
\hline $\begin{array}{l}\text { Dendrophryniscus brevipollicatus Jiménez de la } \\
\text { Espada, } 1870\end{array}$ & 0 & 0 & 0 & 0 \\
\hline Rhinella ornata (Spix, 1824) & 0 & 0 & 0 & 0 \\
\hline \multicolumn{5}{|l|}{ Centrolenidae } \\
\hline Vitreorana uranoscopa (Müller, 1924b) & 0 & 2 & 2 & 4 \\
\hline \multicolumn{5}{|l|}{ Craugastoridae } \\
\hline Haddadus binotatus (Spix, 1824) & 0 & 0 & 0 & 0 \\
\hline \multicolumn{5}{|l|}{ Cycloramphidae } \\
\hline Cycloramphus boraceiensis Heyer, 1983 & 2 & 2 & 2 & 6 \\
\hline Thoropa taophora (Miranda-Ribeiro, 1923) & 2 & 2 & 0 & 4 \\
\hline \multicolumn{5}{|l|}{ Hylidae } \\
\hline $\begin{array}{l}\text { Aplastodiscus eugenioi (Carvalho-e-Silva and } \\
\text { Carvalho-e-Silva, 2005) }\end{array}$ & 0 & 1 & 0 & 1 \\
\hline Bokermannohyla sp. (aff. circumdata) & 0 & 1 & 0 & 1 \\
\hline Dendropsophus minutus (Peters, 1872) & 0 & 0 & 0 & 0 \\
\hline Hypsiboas albomarginatus (Spix, 1824) & 0 & 0 & 0 & 0 \\
\hline Ololygon perpusilla (Lutz and Lutz, 1939) & 0 & 0 & 0 & 0 \\
\hline Ololygon trapicheiroi (Lutz and Lutz, 1954) & 2 & 2 & 2 & 6 \\
\hline \multicolumn{5}{|l|}{ Hylodidae } \\
\hline Hylodes asper (Müller, 1924a) & 2 & 2 & 2 & 6 \\
\hline Hylodes phyllodes Heyer and Cocroft, 1986 & 2 & 2 & 2 & 6 \\
\hline \multicolumn{5}{|l|}{ Leptodactylidae } \\
\hline Physalaemus atlanticus Haddad and Sazima, 2004 & 0 & 0 & 0 & 0 \\
\hline \multicolumn{5}{|l|}{ Microhylidae } \\
\hline Chiasmocleis sp. & 0 & 0 & 0 & 0 \\
\hline \multicolumn{5}{|l|}{ Odontophrynidae } \\
\hline Proceratophrys belzebul Dias et al., 2013 & 2 & 2 & 0 & 4 \\
\hline \multicolumn{5}{|l|}{ Phyllomedusidae } \\
\hline Phasmahyla cruzi Carvalho-e-Silva et al., 2009 & 0 & 2 & 2 & 4 \\
\hline
\end{tabular}

contrast, we did not detect DNA of any non-stream species (Table 2). All species detected through eDNA metabarcoding were observed at least in one month of traditional survey. For four species, we detected DNA in those streams where they were always constant during traditional surveys (Cycloramphus boraceiensis, Hylodes asper, H. phyllodes, and Phasmahyla cruzi; Table 2). Thoropa taophora was also constantly found in four streams, but its DNA was only detected in streams 1 and 4 (Table 2). For species found at lower constancies, we failed to detect their DNA in some of the streams where they were observed during

a)

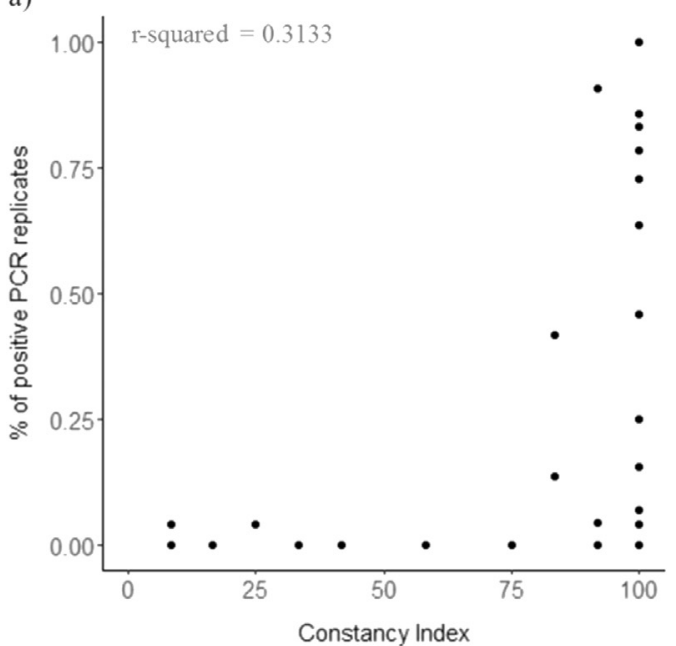

traditional surveys (Table 2). Yet, we were able to detect DNA of two species [Aplastodiscus eugenioi (Carvalho-e-Silva and Carvalho-e-Silva, 2005) in stream 3 and Bokermannohyla sp. (aff. circumdata) in stream 2], that were accidental during traditional surveys (Table 2; see Table A1 for complete constancy values for each species).

The proportion of positive PCR replicates ranged from $0.08(1 / 12$ PCR replicates) to $1.0(12 / 12$ PCR replicates). The constancy index explained approximately one third of the variation in eDNA detection (i.e., proportion of positive PCR replicates) $\left(\mathrm{r}^{2}=0.3133, \mathrm{p}<0.01\right)$ (Fig. 1a). The HI was positively correlated with eDNA detection ( $\rho=0.7604, \mathrm{p} \ll 0.001$ ) (Fig. 1b). Three species (Cycloramphus boraceiensis, Hylodes asper, and $H$. phyllodes) with the highest constancy index and the highest $\mathrm{HI}$ also had a high proportion of positive detection among eDNA samples.

Although the combined richness of the four streams (10 stream species) was almost completely retrieved by eDNA metabarcoding ( 9 stream species), the species richness retrieved for each stream through eDNA metabarcoding was lower than that estimated based on the 5year traditional survey (Table 2), likely because our eDNA sampling occurred in only one sampling period of four days. Similarity between species composition described by eDNA metabarcoding and by traditional surveys varied from 0.40 to 0.75 when taking into account all months sampled (Table 3). In stream 1, we detected DNA from five of seven stream species observed in traditional survey ( $S=0.71$ for all months sampled). The two species not detected in eDNA metabarcoding results were accidental species [Bokermannohyla. sp. (aff. circumdata) and Proceratophrys belzebul Dias et al., 2013], which were not present in stream 1 from March to May. When taking into account species composition from March to May, all species observed in traditional survey of stream 1 were detected through eDNA metabarcoding $(S=1)$. On the other hand, species composition described by eDNA metabarcoding had low similarity with traditional survey results in stream 2 for all time intervals. In stream 2, we were unable to detect DNA from Aplastodiscus eugenioi, Ololygon trapicheiroi and Thoropa taophora, three species commonly recorded in traditional survey. In stream 3 , we detected DNA of six stream species, including an accidental species ( $A$. eugenioi) that does not typically use high-gradient stream habitats $(\mathrm{HI}=1)$, and was not observed in the traditional survey from March to May, but observed only once in June. On the other hand, we were unable to detect DNA from T. taophora and Vitreorana uranoscopa, two stream species $(\mathrm{HI}=4)$ commonly observed in traditional survey in stream 3 . In stream 4 , the similarity $(S)$ observed was not 1 at any time interval because we failed to detect DNA from an accidental species not closely associated with streams (Bokermannohyla sp. (aff. circumdata),

b)

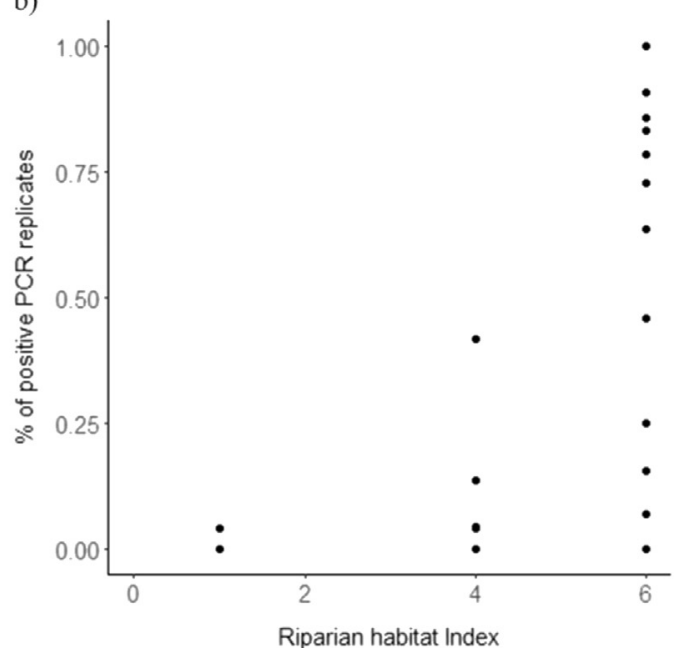

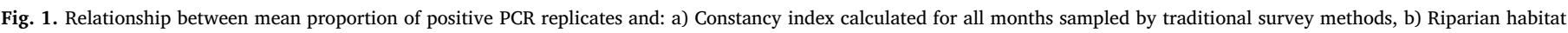
index (HI). 
Table 2

Stream species found through traditional survey (compiling all 55 months of sampling from 2007 to 2011) and eDNA survey in April 2015 in each stream. * indicates species present from March through May pooled across 5 years of traditional survey, and $\cdot$ indicates species present in April pooled across 5 years of traditional survey.

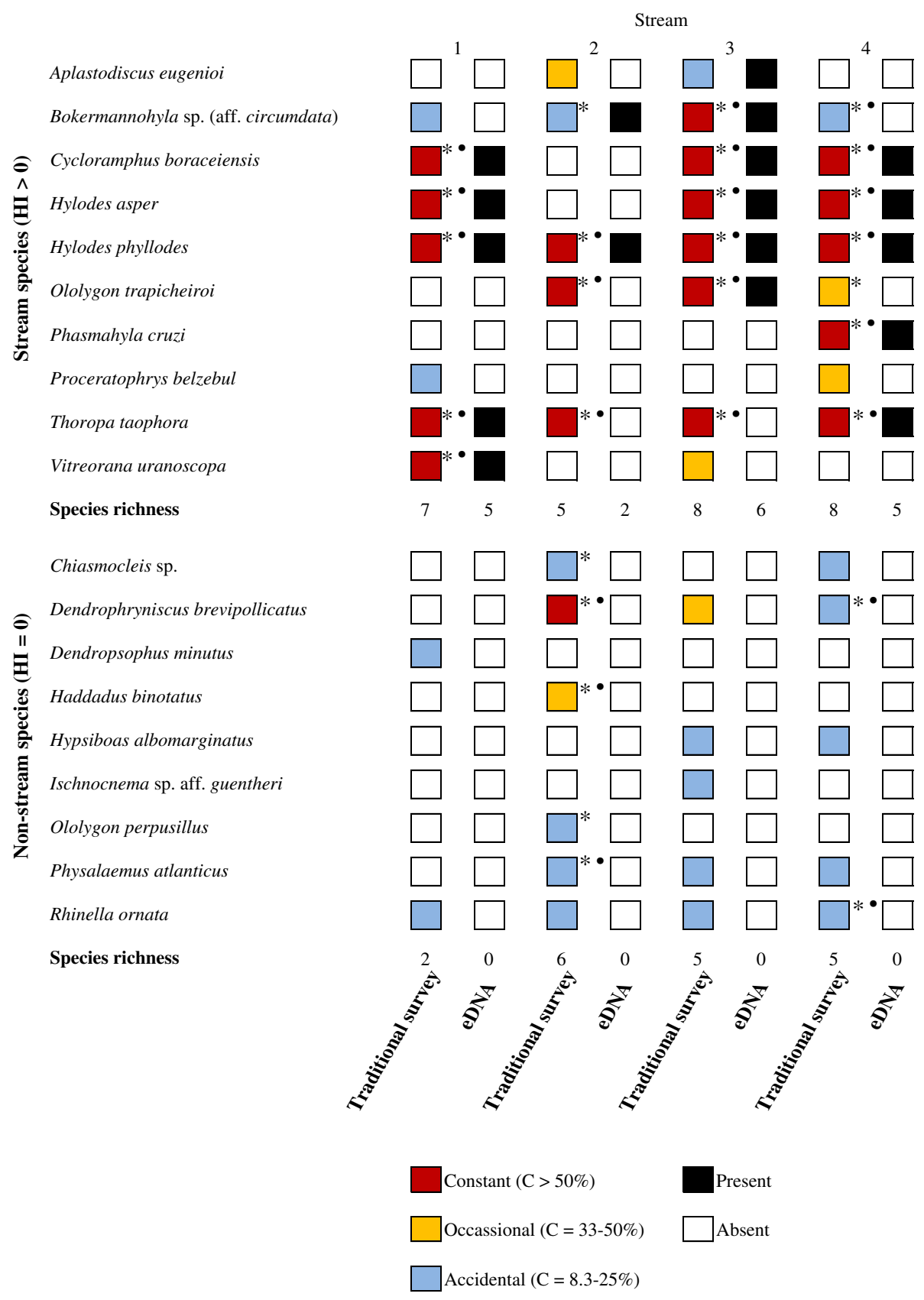

Table 3

Jaccard's index $(S)$ between species composition from eDNA metabarcoding and traditional-survey results, taking into account only stream species (HI $>0$; see Table 1$)$. Similarity in species composition was calculated for each stream and at three time intervals: (i) all months sampled, (ii) the months of March, April, and May, and (iii) only the month of April (same period water samples were filtered for eDNA).

\begin{tabular}{lllc}
\hline Stream & All months & March + April + May & April \\
\hline 1 & 0.71 & 1.00 & 1.00 \\
2 & 0.40 & 0.50 & 0.25 \\
3 & 0.75 & 0.71 & 0.71 \\
4 & 0.62 & 0.71 & 0.83 \\
\hline
\end{tabular}

$\mathrm{HI}=1$ ), and from two occasional species (O. trapicheiroi and $P$. belzebul), closely associated with streams $(\mathrm{HI} \geq 4)$, but which were never observed in April of any year, period when we sampled for eDNA (Table 2).

\section{Discussion}

Our study showed that eDNA metabarcoding is a reliable method for detecting a large proportion of the amphibian communities of stream frogs in the Atlantic forest, but it is not perfect. Remarkably, with a single four-day sampling we detected DNA of all stream species found across all four streams during our five-year traditional survey, with the exception of a single uncommon species (Proceratophrys belzebul). However, at a finer within-stream scale, a single eDNA sample failed to 
detect species that are known to occur at those sites (Table 2). Despite these differences, our eDNA results highlighted the differential use of stream habitats by amphibians, the advantages of sampling different streams in a given region for a better assessment of species richness and community composition, and the ability of eDNA analysis to detect elusive species that are difficult to find during traditional surveys.

Overall, species composition detected by eDNA metabarcoding in each stream showed high similarities to that obtained with traditional surveys, especially when considering only constant species. With a few exceptions, species frequently recorded through traditional survey were reliably detected in eDNA metabarcoding results (Table 2). The exceptions were mainly due to the non-detection of species recorded only once or twice, and mainly in stream 2, the smallest stream that dries out in some years, reducing its use by some species or even hindering the eDNA efficacy. Estimates of species composition by the two approaches also differed because eDNA detected rare species not recovered in traditional surveys during the same time of year. The identification of rare species with eDNA metabarcoding may reflect the fact that life stages not quantified in traditional surveys (e.g., tadpoles or eggs) contributed to DNA available in the water. Alternatively, these species might be present in the region, but occurring further upstream, too far from our transect to be detected by traditional surveys, yet close enough to contribute with detectable eDNA in our downstream sampling points (Deiner and Altermatt, 2014).

Our single four-day eDNA sampling detected almost all (nine of ten) stream species found during the long-term, time and labor-expensive traditional survey. In a single eDNA sampling, we were able to detect rare and elusive species. For instance, in stream 3, we detected DNA of Aplastodiscus eugenioi, which was recorded only once during five years of traditional surveys at this stream. Previous studies have also compared the efficacy of eDNA analysis with traditional survey results for detecting community composition. Thomsen et al. (2012) showed that eDNA analysis recovered fish diversity from seawater samples better than or equal to nine other traditional methods. The idea that eDNA analysis is equally or more efficient than traditional surveys is becoming commonplace (Roussel et al., 2015), although this is based on just a few comparative studies where species abundance is not always reported.

We found a strong positive relationship between eDNA detection and the habitat index (HI), which estimates the degree of contact of a species at different life stages with lotic waters, confirming that specific frog life cycle characteristics are important to consider in eDNA detection. In the Brazilian Atlantic forest, frogs show a great diversity of reproductive modes and life histories, with species exploiting a diversity of humid habitats at different stages in their life cycle (Haddad and Prado, 2005). For instance, adults of Aplastodiscus eugenioi are arboreal, their eggs are deposited in subterranean constructed nests, and the tadpoles develop in ponds near streams or in streams $(\mathrm{HI}=1$; Hartmann et al., 2010). Adults of Vitreorana uranoscopa $(\mathrm{HI}=4)$ and Phasmahyla cruzi $(\mathrm{HI}=4)$ are also arboreal and their eggs are laid on leaves overhanging streams, where tadpoles drop to feed and complete development (Costa et al., 2010; Hartmann et al., 2010). Eggs and tadpoles of Ololygon trapicheiroi, however, can be found in isolated ponds adjacent to streams, which connect with the main stream flow during heavy rains, and calling males are mainly found on trees and shrubs along streams (HI = 6; Hartmann et al., 2010; M. Martins, pers. obs.). Postmetamorphic individuals and tadpoles of Thoropa taophora may be found far from streams, but always close to or on wet rocks along streams, while their eggs are semiterrestrial ( $\mathrm{HI}=4$; Hartmann et al., 2010), which may decrease the chances of finding DNA in water samples in streams in which we know they occur. Unlike the species loosely associated with streams (e.g., A. eugenioi), Cycloramphus boraceiensis, Hylodes asper, and $H$. phyllodes use lotic waters as their primary habitat across life stages and adult individuals can be found on rocks along streams ( $\mathrm{HI}=6$ for the three species). Hylodes asper and $H$. phyllodes lay their eggs in subaquatic chambers and tadpoles develop in streams, while eggs of $C$. boraceiensis are semiterrestrial, with tadpoles living on wet rocks along streams (Hartmann et al., 2010). Not surprisingly, the latter three species were detected in higher proportions in eDNA samples. As expected, all sampled eDNA matched amphibian species with at least one phase of its life cycle associated with streams, and we did not recover DNA from exclusively terrestrial species with direct development or from those that breed in ponds away from streams. Thus, recovery of eDNA shed in water is tightly connected with amphibian life history traits.

We found a relatively weak relationship between eDNA detection and constancy index; nonetheless, some species with the highest constancy values had higher number of positive PCR replicates. For example, common species such as Cycloramphus boraceiensis, Hylodes asper, and $H$. phyllodes that are continuous breeders (Hartmann, 2004; Ruggeri et al., 2015) were found throughout the year, had high constancy values, and also the highest proportions of eDNA positive replicates. The DNA of these species may be released in the environment constantly and in higher amounts. In the case of more seasonal species, such as Ololygon trapicheiroi and Vitreorana uranoscopa (Hartmann, 2004), tadpoles are present during many months in the water and are likely the main contributors of eDNA to water samples, but possibly in lower constancy and quantity.

Environmental DNA analyses have primarily been applied in temperate regions (Hoffmann et al., 2016), despite the fact that tropical streams host complex and often more diverse communities that can differ at very small geographic scales, as illustrated by our traditional survey results. Our study is the first effort to apply eDNA metabarcoding from aquatic samples to characterize frog communities in the Brazilian Atlantic forest, which harbors high anuran richness. Additionally, few studies to date have used eDNA from freshwater systems to detect community assemblages and to identify multiple species from one sample. Minamoto et al. (2012) were the first to report the detection of multiple vertebrate species by amplifying fish eDNA with degenerate primers in Japan. Evans et al. (2016) later measured the species richness of fish and amphibians using eDNA metabarcoding in experimental conditions and showed that some primers can accurately identify species assemblages with differing species densities. Kelly et al. (2014) and Shaw et al. (2016) accurately characterized fish communities in controlled aquatic settings and in rivers, respectively, using primers for vertebrate-specific fragments from mitochondrial genes. Finally, Valentini et al. (2016) surveyed amphibians and fishes in a wide range of aquatic ecosystems in Europe. Here, we demonstrated the value and shortcomings of eDNA detection approach for monitoring vertebrate communities in a tropical environment. Our sampling of eDNA over a single four-day period was able to characterize anuran communities and identify amphibian assemblages with differing species composition, which included elusive species and even some species not tightly associated with streams.

One challenge of working with tropical amphibians is that some species are poorly represented in public sequence databases and taxonomic errors in online databases can compromise the assignment of eDNA sequences (Hoffmann et al., 2016). Shaw et al. (2016), for instance, could not detect some fish taxa from freshwater eDNA samples using $12 \mathrm{~S}$ or $16 \mathrm{~S}$ rRNA mitochondrial primers due to a lack of reference data in the NCBI database. We circumvented this situation by using a local sequence reference database using specimens collected in the region of our study site (Lopes et al., 2017). This is an important stage in bioinformatics analyses, and whenever possible, future studies using eDNA should also count on a local sequence reference database to improve eDNA results, although this demands previous knowledge of species composition in the study region. General knowledge of species occurrence in the study region is also fundamental to avoid mistaken identifications. Another concern when working with amphibians from Atlantic forest is that the knowledge of species occurrence is still incomplete, with cases of taxonomic uncertainty and cryptic undescribed species. Therefore, special caution must be taken when interpreting 
eDNA metabarcoding results for community studies.

\section{Conclusions}

Freshwater ecosystems are essential for a large percentage of the world's amphibian species (e.g., Stuart et al., 2008). Despite their value, riparian habitats are being severely disturbed and declines in freshwater biodiversity are far greater than in terrestrial ecosystems (Dudgeon et al., 2006). The conservation management required is limited by the paucity of rigorous species occurrence data or the difficulty in surveying species in nature. In light of the added sensitivity of next-generation sequencing technology, eDNA metabarcoding is becoming an important tool for addressing practical problems in vertebrate conservation, such as monitoring communities and endangered species or filling knowledge gaps of Data-deficient species. Here we investigated the possible use of eDNA analysis as an additional tool for understanding community composition within streams networks. Given the high richness and endemicity of Atlantic forest amphibians, concomitant with the high degree of endangerment (Gascon et al., 2007; Stuart et al., 2008; Verdade et al., 2012; ICMBio, 2016c), our study showed that eDNA metabarcoding can be a reliable tool to assess amphibian community diversity in streams. Thus, eDNA improves the "ecology toolbox" and will likely enhance conservation efforts of Neotropical amphibians.

Supplementary data to this article can be found online at http://dx. doi.org/10.1016/j.biocon.2017.09.015.

\section{Acknowledgements}

This work was supported by São Paulo Research Foundation (FAPESP) grants \#2006/58011-4, \#2010/50146-3, and \#2013/507417, and Conselho Nacional de Desenvolvimento Científico e Tecnológico (CNPq) grant \#401729/2013-3. We thank Coordenação de Aperfeiçoamento de Pessoal de Nível Superior and FAPESP (grants \#2014/06795-8 and \#2016/14054-3 to T.S.L. and C.M.L., respectively) for scholarships provided during this project. C.M.L., K.R.Z., M.M. and C.F.B.H. thank CNPq for the research fellowships. The help of M. P. Gaiarsa and L. R. V. Alencar was crucial during the 5-year traditional survey; C. Dias, M. Guimarães, D. Gennari, and M. E. Oliveira also helped in the traditional survey. We thank the Instituto Florestal for research and collecting permits (260108-009.752/2014).

\section{References}

Bohmann, K., Evans, A., Gilbert, M.T.P., Carvalho, G.R., Creer, S., Knapp, M., Yu, D.W., Bruyn, M., 2014. Environmental DNA for wildlife biology and biodiversity monitoring. Trends Ecol. Evol. 29 (6), 358-367. http://dx.doi.org/10.1016/j.tree.2014. 04.003 .

Both, C., Lingnau, R., Santos-Jr, A., Madalozzo, B., Lima, L.P., Grant, T., 2011. Widespread occurrence of the American bullfrog, Lithobates catesbeianus (Shaw, 1802) (Anura: Ranidae), in Brazil. South Am. J. Herpetol. 6, 127-134.

Boyer, F., Mercier, C., Bonin, A., Le Bras, Y., Taberlet, P., Coissac, E., 2016. OBITools: a Unix-inspired software package for DNA metabarcoding. Mol. Ecol. Resour. 16, 176-182. http://dx.doi.org/10.1111/1755-0998.12428.

Carvalho, T., Becker, C.G., Toledo, L.F., 2017. Historical amphibian declines and extinctions in Brazil linked to chytridiomycosis. Proc. R. Soc. B 284.

Carvalho-e-Silva, A.M.P.T. de, Carvalho-e-Silva, S.P. de, 2005. New species of the Hyla albofrenata group, from the states of Rio de Janeiro and São Paulo, Brazil (Anura, Hylidae). J. Herpetol. 39, 73-81.

Carvalho-e-Silva, A.M.P.T., Silva, G.R., Carvalho-e-Silva, S.P., 2009. A new species of Phasmahyla Cruz, 1990 from the Atlantic Forest in the state of Rio de Jnaeiro, Brazil (Amphibia, Hylidae, Phyllomedusinae). Zootaxa 2120, 15-26.

CIIAGRO, 2016. Centro integrado de informações agrometeorológicas. http://www. ciiagro.sp.gov.br/ciiagroonline.

Costa, P.N., Carvalho-e-Silva, M.P.T., Flaskman, A., 2010. Egg clutch and larval development of Phasmahyla cruzi (Carvalho-e-Silva, Silva and Carvalho-e-Silva, 2009) (Amphibia, Anura, Hylidae). Herpetology Notes 3, 221-228.

Deiner, K., Altermatt, F., 2014. Transport distance of invertebrate environmental DNA in a natural river. PLoS One 9, e88786. http://dx.doi.org/10.1371/journal.pone. 0088786.

Dejean, T., Valentini, A., Miquel, C., Taberlet, P., Bellemain, E., Miaud, C., 2012. Improved detection of an alien invasive species through environmental DNA barcoding: the example of the American bullfrog Lithobates catesbeianus. J. Appl. Ecol. 49, 953-959. http://dx.doi.org/10.1111/j.1365-2664.2012.02171.x.

Dias, P.H. dos S., Amaro, R.C., Carvalho-e-Silva, A.M.P.T. de, Rodrigues, M.T., 2013. Two new species of Proceratophrys Miranda-Ribeiro, 1920 (Anura; Odontophrynidae) from the Atlantic forest, with taxonomic remarks on the genus. Zootaxa 3682, 277-304.

Dodd, C.K.J., 2010. In: Dodd, C.K.J. (Ed.), Amphibian Ecology and Conservation: A Handbook of Techniques. Oxford University Press, Oxford.

Dudgeon, D., Arthington, A.H., Gessner, M.O., Kawabata, Z., Knowler, D., Lévêque, C., Naiman, R., Prieur-Richard, A.-H., Soto, D., Stiassny, M.L.J., Sullivan, C.A., 2006. Freshwater biodiversity: importance, threats, status and conservation challenges. Biol. Rev. 81, 163-182. http://dx.doi.org/10.1017/S1464793105006950.

Eterovick, P.C., Carnaval, A.O. dos Q., Borges-Nojosa, D.M., Silvano, D.L., Segalla, M.V., Sazima, I., 2005. Amphibian declines in Brazil: an overview. Biotropica 37 (2), $166-179$.

Evans, N.T., Olds, B.P., Renshaw, M.A., Turner, C.R., Li, Y., Jerde, C.L., Mahon, A.R., Pfrender, M.E., Lamberti, G.A., Lodge, D.M., 2016. Quantification of mesocosm fish and amphibian species diversity via environmental DNA metabarcoding. Mol. Ecol. Resour. 16, 29-41. http://dx.doi.org/10.1111/1755-0998.12433.

Feio, R.N., Napoli, M.F., Caramaschi, U., 2006. Considerações taxonômicas sobre Thoropa miliaris (Spix, 1824), com revalidação e redescrição de Thoropa taophora (MirandaRibeiro, 1923) (Amphibia, Anura, Leptodactylidae). 64. Arquivos do Museu Nacional, Rio de Janeiro, pp. 41-60.

Ficetola, G.F., Coissac, E., Zundel, S., Riaz, T., Shehzad, W., Bessière, J., Taberlet, P., Pompanon, F., 2010. An in silico approach for the evaluation of DNA barcodes. BMC Genomics 11, 434.

Gascon, C., Collins, J.P., Moore, R.D., Church, D.R., McKay, J.E., Mendelson IIIJ.R. (Eds.), 2007. Amphibian Conservation Action Plan. IUCN/SSC Amphibian Specialist Group. Gland, Switzerland and Cambridge, UK (64 pp.).

Haddad, C.F.B., Prado, C.P. de A., 2005. Reproductive modes in frogs and their unexpected diversity in the Atlantic forest of Brazil. Bioscience 55, 207-217. http://dx. doi.org/10.1641/0006-3568(2005)055\%5B0207:RMIFAT\%5D2.0.CO;2.

Haddad, C.F.B., Sazima, I., 2004. A new species of Physalaemus (Amphibia; Leptodactylidae) from the Atlantic forest in southeastern Brazil. Zootaxa 479, 1-12.

Haddad, C.F.B., Toledo, L.F., Prado, C.P.A., Loebmann, D., Gasparini, J.L., Sazima, I., 2013. Guia dos Anfíbios da Mata Atlântica: Diversidade e Biologia. Anolis Books (544 pp.).

Hartmann, M.T., 2004. Biologia reprodutiva de uma comunidade de anuros (Amphibia) na Mata Atlântica (Picinguaba, Ubatuba, SP) (Thesis). Universidade Estadual Paulista "Julio de Mesquita Filho", Campus de Rio Claro, Brasil.

Hartmann, M.T., Hartmann, P.A., Haddad, C.F.B., 2010. Reproductive modes and fecundity of an assemblage of anuran amphibians in the Atlantic rainforest, Brazil. Iheringia, Série Zoologia 100, 207-215. http://dx.doi.org/10.1590/S007347212010000300004.

Heyer, W.R., 1983. Variation and systematics of frogs of the genus Cycloramphus (Amphibia, Leptodactylidae). Arquivos de Zoologia 30, 235-339.

Heyer, W.R., 1985. New species of frogs from Boracéia, São Paulo, Brazil. Proc. Biol. Soc. Wash. 98, 657-671.

Heyer, W.R., Cocroft, R.B., 1986. Descriptions of two new species of Hylodes from the Atlantic forests of Brazil (Amphibia: Leptodactylidae). Proc. Biol. Soc. Wash. 99, 100-109.

Heyer, R., Maureen, A.D., Mercedes, F., Roy, M., 1993. Measuring and Monitoring Biological Diversity: Standard Methods for Amphibians. Smithsonian Institution.

Hoffmann, C., Schubert, G., Calvignac-Spencer, S., 2016. Aquatic biodiversity assessment for the lazy. Mol. Ecol. 25, 846-848. http://dx.doi.org/10.1111/mec.13535.

ICMBio, Instituto de Conservação Chico Mendes da Biodiversidade, 2016a. Listas das Espécies da Fauna Brasileira Ameaçadas de Extinção. http://www.icmbio.gov.br/ portal/faunabrasileira/lista-de-especies.

ICMBio, Instituto de Conservação Chico Mendes da Biodiversidade, 2016b. Lista de Espécies Quase Ameaçadas e Com Dados Insuficientes. http://www.icmbio.gov.br/ portal/faunabrasileira/lista-de-especies-dados-insuficientes.

ICMBio, Instituto de Conservação Chico Mendes da Biodiversidade, 2016c. Plano de Ação Nacional para Conservação da Herpetofauna Ameaçada da Mata Atlântica da Região Sudeste do Brasil. http://www.icmbio.gov.br/portal/faunabrasileira/plano-de-acaonacional-lista/3617-plano-de-acao-nacional-para-conservacao-da-herpetofaunaameacada-da-mata-atlantica-da-regiao-sudeste-do-brasil.

IUCN, 2015. The IUCN red list of threatened species. http://www.iucnredlist.org.

Jiménez de la Espada, M., 1870. Fauna neotropicalis species quaedam nondum cognitae. J. Sci. Math. Phys. Nat. 3, 57-65 (Lisboa).

Kelly, R.P., Port, J.A., Yamahara, K.M., Crowder, L.B., 2014. Using environmental DNA to census marine fishes in a large mesocosm. PLoS One 9, e86175. http://dx.doi.org/10. 1371/journal.pone.0086175.

Köppen, W., 1948. Climatologia: con un estudio de los climas de la tierra. Fondo de Cultura Econômica, México (479 pp.).

Krebs, C.J., 1998. Ecological Methodology. Benjamin/Cummings, Menlo Park, California.

Lips, K.R., Reeve, J.D., Witters, L.R., 2003. Ecological traits predicting amphibian population declines in Central America. Conserv. Biol. 17, 1078-1088. http://dx.doi. org/10.1046/j.1523-1739.2003.01623.x.

Lopes, C.M., Sasso, T., Valentini, A., Dejean, T., Martins, M., Zamudio, K.R., Haddad, C.F.B., 2017. eDNA metabarcoding: a promising method for anuran surveys in highly diverse tropical forests. Mol. Ecol. Resour. http://dx.doi.org/10.1111/1755-0998. 12643.

Lutz, A., 1924. Sur les rainettes des environs de Rio de Janeiro. In: Comptes Rendus et Mémoires Hebdomadaires des Séances de la Société de Biologie et des ses Filiales. 1. pp. 241.

Lutz, A., Lutz, B., 1939. New Hylidae from Brazil/Hylideos novos do Brasil. An. Acad. Bras. Cienc. 11, 67-89. 
Lutz, A., Lutz, B., 1954. Anfibios anuros do Distrito Federal/The frogs of the Federal District of Brazil. 52 Memórias do Instituto Oswaldo Cruz (155-197 (Portuguese), 219-238 (English)).

Minamoto, T., Yamanaka, H., Takahara, T., Honjo, M.N., Kawabata, Z., 2012. Surveillance of fish species composition using environmental DNA. Limnology 13, 193-197. http://dx.doi.org/10.1007/s10201-011-0362-4.

Miranda-Ribeiro, A. de, 1923. Os hylodideos do Museu Paulista. Revista do Museu Paulista 13, 825-846.

Morellato, P., Haddad, C.F.B., 2000. Introduction: the Brazilian Atlantic Forest. Biotropica 32, 4,786-792. http://dx.doi.org/10.1111/j.1744-7429.2000.tb00618.x.

Müller, L., 1924a. Neue Batrachier aus Ost-Brasilien. Senckenberg. Biol. 6, 169-177.

Müller, L., 1924b. Neue laubfrösche aus dem Staate Santa Catharina, S. O. Brasilien. Zool. Anz. 59, 233-238.

Myers, N., Mittermeier, R.A., Mittermeier, C.G., Fonseca, G.A.B. da, Kent, J., 2000 Biodiversity hotspots for conservation priorities. Nature 403, 72. http://dx.doi.org/ 10.1038/35002501.

Peters, W.C.H., 1872. Über eine Sammlung von Batrachiern aus Neu Freiburg in Brasilien. Monatsberichte der Königlichen Preussische Akademie des Wissenschaften zu Berlin. pp. 680-684.

Petitot, M., Manceau, N., Geniez, P., Besnard, A., 2014. Optimizing occupancy surveys by maximizing detection probability: application to amphibian monitoring in the Mediterranean region. Trends Ecol. Evol. 4, 3538-3549. http://dx.doi.org/10.1002/ ece3.1207.

R Development Core Team, 2015. R: A Language and Environment for Statistical Computing. R Foundation for Statistical Computing, Vienna. http://www.R-project. org.

Ribeiro, M.C., Metzger, J.P., Martensen, A.C., Ponzoni, F.J., Hirota, M.M., 2009. The Brazilian Atlantic Forest: how much is left, and how is the remaining forest distributed? Implications for conservation. Biol. Conserv. 142, 1141-1153. http://dx. doi.org/10.1016/j.biocon.2009.02.021.

Roussel, J.-M., Paillisson, J.-M., Tréguier, A., Petit, E., 2015. The downside of eDNA as a survey tool in water bodies. J. Appl. Ecol. 52, 823-826. http://dx.doi.org/10.1111/ 1365-2664.12428.

Ruggeri, J., Longo, A.V., Gaiarsa, M.P., Alencar, L.R.V., Lambertini, C., Leite, D.S., Carvalho-e-Silva, S.P., Zamudio, K.R., Toledo, L.F., Martins, M., 2015. Seasonal variation in population abundance and chytrid infection in stream-dwelling frogs of the Brazilian Atlantic Forest. PLoS One 10, e0130554.

Shaw, J.L.A., Clarke, L.J., Wedderburn, S.D., Barnes, T.C., Weyrich, L.S., Cooper, A.,
2016. Comparison of environmental DNA metabarcoding and conventional fish survey methods in a river system. Biol. Conserv. 197, 131-138. http://dx.doi.org/10 1016/j.biocon.2016.03.010.

Silveira-Netto, S., Nakano, O., Barbin, D., Villa-Nova, N.A., 1976. Manual de ecologia dos insetos. São Paulo, Agronômica Ceres (419 pp.).

Spix, J.B.v., 1824. Animalia nova sive Species novae Testudinum et Ranarum quas in itinere per Brasiliam annis MDCCCXVII-MDCCCXX jussu et auspiciis Maximiliani Josephi I. Bavariae Regis. F. S. Hübschmann, München.

Stuart, S.N., Hoffmann, M., Chanson, J.S., Cox, N.A., Berridge, R.J., Ramani, P., Young, B.E. (Eds.), 2008. Threatened Amphibians of the World. Lynx Edicions, Barcelona, Spain; IUCN, Gland, Switzerland; and Conservation International, Arlington, Virginia, USA.

Taberlet, P., Coissac, E., Hajibabaei, M., Rieseberg, L.H., 2012a. Environmental DNA. Mol. Ecol. 21, 1789-1793. http://dx.doi.org/10.1111/j.1365-294X.2012.05542.x.

Taberlet, P., Coissac, E., Pompanon, F., Brochmann, C., Willerslev, E., 2012b. Toward next-generation biodiversity assessment using DNA metabarcoding. Mol. Ecol. 21, 2045-2050. http://dx.doi.org/10.1111/j.1365-294X.2012.05470.x.

Thomsen, P.F., Willerslev, E., 2015. Environmental DNA - an emerging tool in conservation for monitoring past and present biodiversity. Biol. Conserv. 183, 4-18. http://dx.doi.org/10.1016/j.biocon.2014.11.019.

Thomsen, P., Kielgast, J., Iversen, L.L., Møller, P.R., Rasmussen, M., Willerslev, E., 2012 Detection of a diverse marine fish fauna using environmental DNA from seawater samples. PLoS One 7, e41732. http://dx.doi.org/10.1371/journal.pone.0041732.

Valentini, A., Taberlet, P., Miaud, C., Civade, R., Herder, J., Thomsen, P.F., Bellemain, E., Besnard, A., Coissac, E., Boyer, F., Gaboriaud, C., Jean, P., Poulet, N., Roset, N., Copp, G.H., Geniez, P., Pont, D., Argillier, C., Baudoin, J.M., Peroux, T., Crivelli, A., Olivier, A., Acqueberge, M., Le Brun, M., Moller, P.R., Willerslev, E., Dejean, T., 2016. Nextgeneration monitoring of aquatic biodiversity using environmental DNA metabarcoding. Mol. Ecol. 25, 929-942. http://dx.doi.org/10.1111/mec.13428.

Verdade, V.K., Valdujo, P.H., Carnval, A.C., Schiesari, L., Toledo, L.F., Mott, T., Andrade, G.V., Eterovick, P.C., Menin, M., Pimenta, B.V.S., Nogueira, C., Lisboa, C.S., De Paula, C.D., Silvano, D.L., 2012. A leap further: the Brazilian amphibian conservation action plan. Alytes 29, 27-42.

Wilcox, T.M., Schwartz, M.K., McKelvey, K.S., Young, M.K., Lowe, W.H., 2014. A blocking primer increases specificity in environmental DNA detection of bull trout (Salvelinus confluentus). Conserv. Genet. Resour. 6, 283-284. http://dx.doi.org/10.1007/ s12686-013-0113-4. 